\title{
The Application of Coordinate Translation Model (CTM) in Medical Translation Practice
}

\author{
Luu Trong Tuan \\ University of Finance-Marketing, Ho Chi Minh City, Vietnam \\ Email: luutrongtuan@vnn.vn
}

\begin{abstract}
Since human beings speak different tongues, translation exists (Steiner, 1975, p. 51). Translation, furthermore, exists partly as human contributions to science and technology need to be globally shared. Thus, scientific translation can not be ignored due to its mission to disseminate scientific knowledge beyond the national borders. This research sought to explore if medical students can grow out of medical translation difficulties and enjoy translation activity which Karra (2000) depicts as "magical task". 79 fouth-year students from the two classes, one treated as the experimental group (EG) and the other as the control group (CG), from Pham Ngoc Thach University of Medicine (PNTUM), who were attending the fourth course of English (English 4), were invited to participate in the research, whose findings gave a glimpse back at strengths and weaknesses in students' medical translation skill as well as demonstrated the positive impact of the application of Coordinate Translation Model (CTM) on the quality of learners' medical translation.
\end{abstract}

Index Terms - scientific translation, medical translation, translation unit, Coordinate Translation Model (CTM)

\section{INTRODUCTION}

In human history, cultural exchange commenced along with the emergence of culture. Translation, a cultural phenomenon and a means of cultural exchange, has brought a community beyond its spatial and temporal dimensions as contended by Kelly (2004): "Without translation, there is no history of the world." Without translation, our world would encompass secluded oases, which would develop separately and have their own histories without contributing to the world history.

Translation in general and scientific translation in particular have formed a bridge for the exchange of scientific knowledge, which has exposed a scientific community to the discoveries and inventions of mankind. Together with the entry of Western medicine, medical translation has produced the shift in Vietnamese beliefs about the pathogenesis of malaria from the toxicity of water, which led to the formation of the term Sốt rét ngã nước (malaria caused by the toxic water), to the Plasmodium parasite, and removed the morphs ngã nước (caused by the toxic water) from the term.

Notwithstanding the value of scientific translation as a "pollinator of science" (Fishbach, 1993), numerous scientists nowadays turn their back on the contributions of translation as well as the usefulness of translation skill by maintaining that translation is a roundabout path to the fast flux of scientific information in the world compared to their direct approach via their own English competence. Scientists also hesitate to visit translated scientific texts due to their semantic divergence from the souce texts or their low readability. Scientific translation, furthermore, is portrayed as poorly written by Newmark (1988, p. 160) and even as mundane and mechanical and lacking in academic value by Schleiermacher (1813, cited in Snell-Hornby, 1988, p. 11).

Does scientists' individual approach to science through their own English proficiency, nonetheless, assume communitivity? Human knowledge is the common asset, and translation assists in deciphering linguistic codes and thereby sharing this asset with the wider community as alleged by Bui (2006) that translation is to increase the power of the community and to enable the next generations to fly high and far. Without that common ground, the sudden "creativity" is hardly of quality except a bit of empty fame and contrasts with "exotericism" (not "esotericism"), which is inherently the nature of science and humanity (Bui, 2006).

Building scientific translation skill in students enables them to share their knowledge with their colleagues as well as with the community. This research sought to locate where learners were in their translation practice and explore whether, through the application of Coordinate Translation Model (CTM) introduced to them, they could grow out of translation difficulties and enjoy translation activity which Karra (2000) depicts as "magical task".

The study was, therefore, guided by the two subsequent research questions:

1. What are strengths and weaknesses in students' medical translation skill?

2. Can the application of Coordinate Translation Model (CTM) enhance students' medical translation practice?

\section{COORDINATE TRANSLATION MODEL}

The rendezvous among translation theories and models is the quest for the equivalents in the target language, the first step of which is to spot the translation units defined by Zhu (1999) as: 
The smallest segment[s] of an SL text which can be translated as an independent and integrated meaning entity in relation to other segments of the text. Its formal realization, if viewed in isolation, is analyzable on levels ranging from the morpheme to the sentence; its textual potential, however, is based on the completeness of its information structure, and is normally realized when it performs textual functions in the SL text. These textual functions are to be matched in the construction of a TL text.

The journey to translation units is depicted by Walter Benjamin as reaching the tryst where the translation and the source text echo the same pitch (see Cao, 2005).

Thus, a translation model should have two axes: translation unit axis and concept equivalent axis. The translator will move along translation unit axis to locate the translation unit, then project to concept equivalent axis to see if the equivalent exists in the target language. Moreover, language task schema axis which scans along the source text is needed. Language task schema, one of the three basic loci of control in the Inhibitory Control (IC)) model of Green (1998a, b), is established by the translator to translate between languages.

Therefore, Coordinate Translation Model is proposed (by the author of this paper) to be built upon three axes: $\mathrm{X}$ axis - translation unit axis, $\mathrm{Y}$ axis - concept equivalent axis, and $\mathrm{Z}$ axis - language task schema axis as illustrated in Figure 1 (In Euclidean geometry, a translation is moving every point a constant distance in a specified direction).

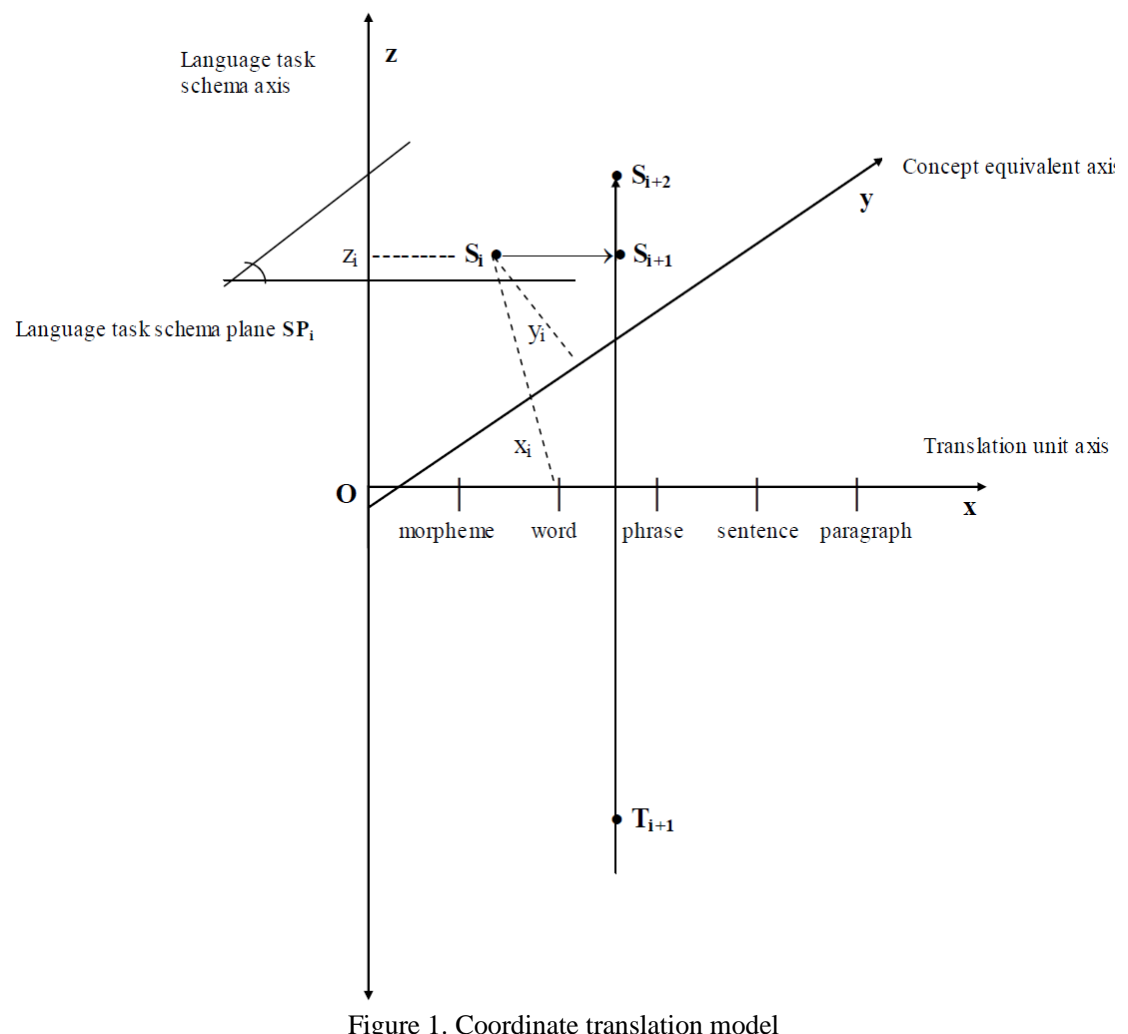

So as to locate the translation unit xi, the translator tends to move from the start of a sentence searching phrases. For instance, as the translator reaches a noun phrase and find it a term, she or he decomposes it into words and consider words as translation units $(\mathrm{xi}=$ word). However, in case the translator projects to the concept equivalent axis, i.e. project to the target language, and find no $\mathrm{Ti}$ (xi, yi, -zi) (T=target) (-zi in the target language is symmetrical to zi in the source language) equivalent to $\mathrm{Si}(\mathrm{xi}, \mathrm{yi}, \mathrm{zi})(\mathrm{S}=$ source). Then, the translator will move from $\mathrm{Si}$ to $\mathrm{Si}+1$ (xi+1, yi+1, zi) $(\mathrm{Si}+1$ has the coordinate $\mathrm{zi}$ since it remains on the same language task schema plane as $\mathrm{Si}$ ), i.e. move from xi (word) $\rightarrow$ $\mathrm{xi}+1$ (phrase), and in this case, encounter its equivalent $\mathrm{Ti}+1$ (xi+1, yi+1, -zi) in the target language. For example, at the point Si of the source text, the translator comes across the noun phrase "cradle cap". If the translator chooses word as the translation unit: $x i=$ word $=\{[$ cradle $][$ cap $]\}$, then she or he is unable to find the equivalent Ti (xi, yi, $-z i)$; nonetheless, if the translator moves from $\mathrm{xi} \rightarrow \mathrm{xi}+1=$ word $\rightarrow$ phrase, then she or he will find the equivalent in the target language, which involves the relationship between [cradle] and [cap] $=$ [cradle] $R$ [cap] $=\{$ scalp lesion due to lying in the cradle $\}=\{$ dermatitis of the infants' scalp $\}$.

Another illustration is the process of translating the passive construction from English to Vietnamese language. If the translator selects word as the translation unit: $\mathrm{xi}=$ word $=\{[$ be][past participle] $\}$, then she or he is incapable of reaching pragmatic equivalence and formal asthetic equivalence (Koller, 1992) in the target language since the passive structure is "copied" from English to Vietnamese language. If the translator, however, moves from $x i \rightarrow x i+1=$ word $\rightarrow$ phrase, then she or he will find the equivalent in the target language, which entails, as in below example, the conversion of the passive structure into the active structure in the target language. 
When the passive structure is parallel to the active structure in the sentence, it tends to be translated as the active structure in the target language:

$$
\left.\left\{\left(\text { be }+\mathrm{PP}\left(\mathrm{V}_{1}\right)\right) \text { AND } \mathrm{V}_{2}\right\} \underset{\text { translate }}{\longrightarrow} \text { active equivalent }\left(\mathrm{V}_{1}\right) \text { VÀ } \mathrm{V}_{2}\right\}
$$

\begin{tabular}{|l|l|l|}
\hline Source text & Source-oriented translation & Source-independent translation \\
\hline $\begin{array}{l}\text { Gastrointestinal discomfort and bleeding } \\
\text { are often encountered and may be severe. }\end{array}$ & $\begin{array}{l}\text { Rối loạn và xuất huyết tiêu hóa thuờng } \\
\text { đuợc gặp và có thể trầm trọng. }\end{array}$ & $\begin{array}{l}\text { Rối loạn và xuất huyết tiêu hóa thuờng } \\
\text { xảy ra và có thể trầm trọng. }\end{array}$ \\
\hline
\end{tabular}

It is the motion from $\mathrm{xi} \rightarrow \mathrm{xi}+1=$ word $\rightarrow$ verbal phrase which contributes to the location of the equivalent $\mathrm{Ti}+1(\mathrm{xi}+1$, $\mathrm{yi}+1,-\mathrm{zi})$ - the active structure - in the target language.

On the contrary, when the passive structure in the source text is a ring of the theme-rheme chain $\{\mathrm{T} 1, \mathrm{R} 1 \rightarrow \mathrm{T} 1, \mathrm{R} 2$ (passive) $\}$, its translation should retain the passive structure to sustain the theme-rheme chain.

$$
\left\{\mathrm{T}_{1}, \mathrm{R}_{1} \rightarrow \mathrm{T}_{1}, \mathrm{R}_{2} \text { (passive) }\right\} \underset{\text { translate }}{\stackrel{2}{\longrightarrow}}\left\{\mathrm{T}_{1}, \mathrm{R}_{1} \rightarrow \mathrm{T}_{1}, \mathrm{R}_{2} \text { (passive) }\right\}
$$

\begin{tabular}{|c|c|c|}
\hline Source text & Using the active structure & Using the passive structure \\
\hline $\begin{array}{l}\text { Aspirin and acetaminophen are the drugs } \\
\text { of choice. } \\
\text { These drugs should be given regularly } \\
\text { (325-650 mg q3-4h) until the underlying } \\
\text { disease process has been controlled. }\end{array}$ & $\begin{array}{l}\text { Aspirin và acetaminophen là các thuốc } \\
\text { được chọn dùng. Nên dùng các thuốc này } \\
\text { đều đặn ( } 325-650 \text { mg mối 3-4 giờ) cho } \\
\text { đến khi kiểm soát được tiến triển của bệnh } \\
\text { nền. }\end{array}$ & $\begin{array}{l}\text { Aspirin và acetaminophen là các thuốc } \\
\text { được chọn dùng. Các thuốc này nên đuợc } \\
\text { dùng đều đặn (325-650 mg mỗi 3-4 giờ) } \\
\text { cho đến khi kiểm soát được tiến triển của } \\
\text { bệnh nền. }\end{array}$ \\
\hline
\end{tabular}

Since the source text contains the parallel theme-rheme chain:

Aspirin và acetaminophen là các thuốc được chọn dùng. Các thuốc này nên dùng đều đặn ...

$\mathrm{T} 1$

the subject "Các thuốc này" (These drugs) in the second sentence should not be placed after the active verb "Nên dùng" (Please give), but rather, the translation of this sentence should retain the passive structure: "Các thuốc này nên được dùng đều đặn ..."

The decision to retain the passive structure does not lie in the fact that the translation unit $x i=$ word or $x i+1=v e r b a l$ phrase, but the translator moves beyond $x i+2=$ sentence, to arrive at $x i+3=$ paragraph (intersentential theme-rheme chain) to attain pragmatic equivalence and formal asthetic equivalence in the Vietnamese language.

When the translator engages in translating a text, she or he starts at the point S0 of the text, which is the title of the text, on the language task schema plane SP0 at the coordinate O. At S0 (x0, y0, z0), the translator will identify the translation unit to translate the text title, for instance, "White Blood Cell Counts and Heart Attacks". When discovering that $\mathrm{x} 0=$ word does not have its equivalent $\mathrm{T} 0$ in Vietnamese language since this translation unit will lead to the translation "Đếm tế bào máu trắng và những cơn tấn công tim" ("Counting white blood cells and attacking heart), the translator moves from $\mathrm{x} 0$ (word) $\rightarrow \mathrm{x} 0+1$ (phrase) and encounters its equivalent "Công thức bạch cầu và Cơn đau tim" in Vietnamese language.

From the point S0 (the text title), the language task schema of text type, intrinsic succession of events in the text, topic-related terms will emerge on the plane SP0 as shown in Figure 2. Then, the translator leaves the text title and travels to the point S1 on the language task schema plane SP1. On this plane, the translator will move from S1 to the various points $\mathrm{S} 1 \mathrm{i}$ to translate the first paragraph of the text in the sequence: from $\mathrm{Si}$ to $\mathrm{Si}+1, \mathrm{Si}+1$ to $\mathrm{Si}+2$ as in the general description above.

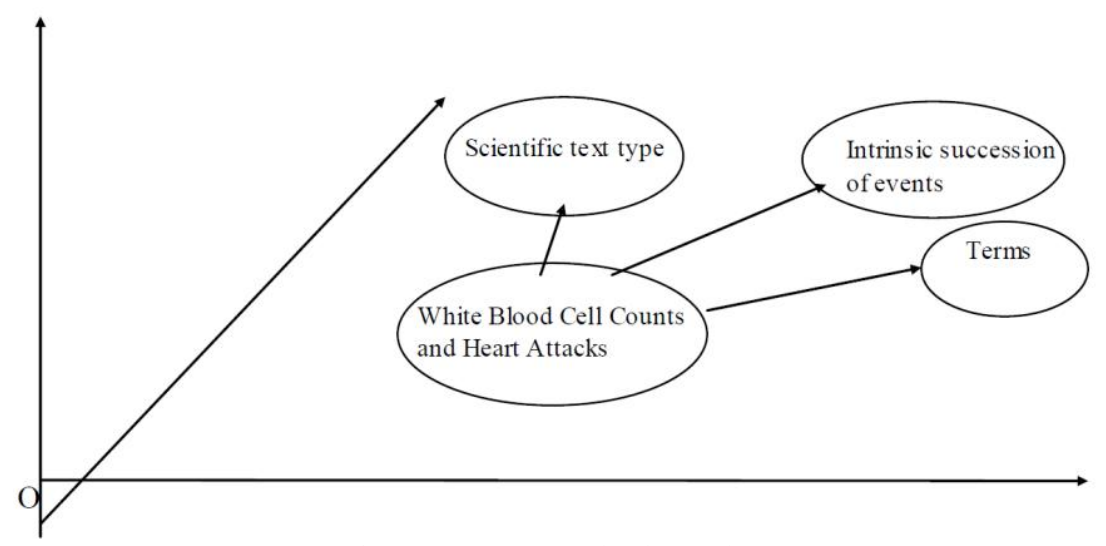

Figure 2. Language task schema plane 
Finishing the translation of a paragraph, the translator looks back at all language task schemata on that language task schema plane for any editing, then travels to the language task schema plane SP2, which is the next paragraph, then to SP3, and so forth, along the axis $\mathrm{Z}$ - the length of the text.

The motion of the cognitive flow between the coordinate axes is "infinitely complex job" as Weaver (1989: 117) put it, "If someone asks me how I translate, I am hard put to find an answer. I can describe the physical process. I make a very rapid first draft, put it aside for a while, then go over it at a painfully slow pace, pencil - and eraser in hand. But that is all outside. Inside the job is infinitely complex."

\section{RESEARCH METHODOLOGY}

\section{A. Participants}

79 fouth-year students (from among a population of 272 fourth-year students), 43 females and 36 males, from the two classes of virtually analogous translation competence level (predicated on the students' scores from the pretest) from Pham Ngoc Thach University of Medicine (PNTUM), who were attending the fourth course of English (English 4) were invited to participate in the research. PNTUM's English syllabus comprises two 75-hour courses of English for General Purposes (EGP) (English 1 \& English 2) and two 75-hour courses of Medical English (English for Specific Purposes) (English $3 \&$ English 4). Besides four fundamental language skills the English syllabus focuses on, medical translation skill is incorporated into the language practice in the two courses English 3 and English 4. Notwithstanding their certain depth of translation experience accumulated from years of high school and courses of English 1 and English 2 through grammar-translation teaching approach (both grammar-translation approach and communicative approach are complementarily applied in English teaching at PNTUM), the students of English 3 course are of too brief history of medical translation practice, which will likely limit in-depth exploration. The reason behind the selection of the fourth-year students was their experience of medical translation practice from the English 3 course. Moreover, they had an extensive history of exposure to medical terminology from the two years (second year and third year) of immersing themselves in such medical subjects as anatomy, physiology, pathology, microbiology, internal medicine, surgery, and pharmacology, as well as exposure to medical texts from reading passages in English 3 materials and from medical articles which clinical practice required them to read. Since the growing need for exploring and translating medical articles for attending medical seminars as well as presenting medical cases emerges in the fourth year of medical study, the invitation to this research was positively accepted by the fourth-year students, which is more likely to lead to cooperative relationship viewed by Stringer (1999, p. 122) as an important aspect of action research.

One fourth-year class (Y06E) was treated as the experimental group (EG), and the other (Y06B) as the control group (CG). The students in the experimental group were immersed in medical translation practice under the teacher's guidance on how to apply Coordinate Translation Model (CTM) rather than literal translation approach or sourceoriented translation approach in which the students in the control group practiced medical translation.

\section{B. Instrumentation and Procedure}

The research consisted of two phases.

Phase 1: Collecting data from medical translation skills questionnaires

A questionnaire survey was intended to explore the medical students' awareness of the importance of translation, their perception of translation method as well as their competence in medical translation. The questionnaire (Appendix 1) comprising 35 multiple choice questions generated by the author had two parts: Part I asked respondents for certain fundamental biographical data, self-assessment of their English proficiency level primarily in terms of reading skill, and awareness of the importance of translation in their career; and Part II sought to identify respondents' medical translation skill as described in Table 1.

TABLE 1.

MEDICAL TRANSLATION SKILLS QUESTIONS SEEK TO IDENTIFY

\begin{tabular}{|c|c|c|c|}
\hline \multicolumn{3}{|l|}{ Identifying } & Questions \\
\hline \multicolumn{3}{|c|}{ Learners' translation method } & $1-4$ \\
\hline \multicolumn{3}{|c|}{ Learners' skill of translating medical terms } & $5-11$ \\
\hline \multirow{3}{*}{$\begin{array}{l}\text { Learners' skills to } \\
\text { translate certain function } \\
\text { words and syntactic } \\
\text { structures }\end{array}$} & \multicolumn{2}{|c|}{ Translating articles } & $12-17$ \\
\hline & $\begin{array}{l}\text { Translating } \\
\text { connectors }\end{array}$ & $\begin{array}{l}\text { Connectors of addition } \\
\text { Connectors of choice } \\
\text { Connectors of comparison } \\
\text { Causal connectors } \\
\text { Connectors of contrast }\end{array}$ & $\begin{array}{l}18-22 \\
23-24 \\
25 \\
26 \\
27-32\end{array}$ \\
\hline & \multicolumn{2}{|c|}{$\begin{array}{l}\text { Translating nominalizations } \\
\text { Translating passive constructions }\end{array}$} & $\begin{array}{l}33 \\
34-35\end{array}$ \\
\hline
\end{tabular}

Phase 2: Investigating the effectiveness of the application of Coordinate Translation Model (CTM) in medical translation practice

Pretest and posttest in the form of translating a medical text were employed as instruments to measure students' medical translation proficiency level. Students' translated texts were assessed using the first method (method A) out of 
Waddington's (2001) four methods of evaluating student translation. Method A, which originates from Hurtado Albir (1995), is predicated on error analysis and potential errors are clustered under the following headings:

(i). Inappropriate renderings which affect the understanding of the source text; these are divided into eight categories: contresens, faux sens, nonsens, addition, omission, unresolved extralinguistic references, loss of meaning, and inappropriate linguistic variation (register, style, dialect, etc.).

(ii). Inappropriate renderings which affect expression in the target language; these are divided into five categories: spelling, grammar, lexical items, text and style.

(iii). Inadequate renderings which affect the transmission of either the main function or secondary functions of the source text.

In each of the categories a distinction is made between serious errors ( -2 points) and minor errors ( -1 point). In the case of the translation test where this method was applied, the sum of the negative points was subtracted from a total of 110 and then divided by 11 to attain a mark from 0 to 10 (which is the normal Vietnamese system). For instance, if a student gets a total of -43 points, his result would be computed as follows: $110-43=67 / 11=6.09$ (which passes; the lowest pass mark is 5).

The initial translation proficiency level of the whole population of fourth-year students was explored by the pretest, from which scores contributed to the choice of the experimental group and control group of practically similar translation competence level. Upon the arrival of the fifteenth week, the students in both experimental group and control group took the post-test, which sought to assess the impact of the application of Coordinate Translation Model (CTM) on the quality of the students' medical translation.

\section{FINDINGS AND DISCUSSION}

Strengths and weaknesses in students' medical translation skill

Of 79 questionnaires delivered to the students to survey their strengths and weakenesses in medical translation, 72 were returned in completed form (91.14\% response rate).

- Analysis of the results from the general information of the questionnaire

TABLE 1.

LEARNERS' SELF-ASSESSMENT OF THEIR ENGLISH COMPETENCE

\begin{tabular}{|c|c|c|c|c|}
\hline Types of English & Mean length of study & $\begin{array}{l}\text { Learners' self-assessment of } \\
\text { their English competence }\end{array}$ & Number of students & Percentage (\%) \\
\hline $\begin{array}{l}\text { English for General } \\
\text { Purposes (EGP) }\end{array}$ & 10.06 years & $\begin{array}{l}\text { Excellent } \\
\text { Good } \\
\text { Adequate } \\
\text { Poor }\end{array}$ & $\begin{array}{l}4 \\
17 \\
33 \\
18\end{array}$ & $\begin{array}{l}5.56 \\
23.61 \\
45.83 \\
25\end{array}$ \\
\hline Medical English & 1.82 years & $\begin{array}{l}\text { Excellent } \\
\text { Good } \\
\text { Adequate } \\
\text { Poor }\end{array}$ & $\begin{array}{l}5 \\
15 \\
28 \\
24\end{array}$ & $\begin{array}{l}6.94 \\
20.83 \\
38.89 \\
33.33\end{array}$ \\
\hline
\end{tabular}

As displayed in Table 1, the students' mean length of studying English for General Purposes (EGP) was 10.06 years, whereas their mean length of immersing themselves in medical English was purely 1.82 years. These figures, nonetheless, were less perturbing than the figures indicating their self-assessment of English competence, which revolved around the adequate level for English for General Purposes and appeared skewed towards the poor level for medical English. These figures alerted as well as required the researcher to provide intensive support for students' acquisition and application of Coordinate Translation Model (CTM) along the research.

TABLE 2.

LEARNERS’ AWARENESS OF THE ROLE OF TRANSLATION IN THEIR MEDICAL CAREER

\begin{tabular}{|l|l|l|l|l|}
\hline \multicolumn{2}{|c|}{ LEARNERS' AWARENESS OF THE ROLE OF TRANSLATION IN THEIR MEDICAL CAREER } \\
\hline Investigating & Question number & \multicolumn{3}{|l|}{ Number of students who chose the answer } \\
\cline { 3 - 5 } & & $\mathrm{A}$ & $\mathrm{B}$ & Other reasons \\
\hline Students' awareness of the importance of & 5 & 68 & 4 & \\
translation in their medical career & 6 & 59 & 52 & \\
\hline
\end{tabular}

The data from Table 2 revealed that 68 of the students, or $94.44 \%$, were aware of the importance of translation in their medical career; furthermore, 59 of the students, or $81.94 \%$, realized that translation skill is for translating medical materials, rather than for comprehending medical texts $(52 / 72$ students $=72.22 \%)$, indicative of the students' high instrumental motivation for their involvement in this research.

- Analysis of the results from the investigation of learners' translation method. 
TABLE 3

LEARNERS' TRANSLATION METHOD

\begin{tabular}{|l|l|l|l|l|l|l|l|}
\hline Investigating & Question number & \multicolumn{6}{|l|}{ Number of students who chose the answer } \\
\cline { 3 - 7 } & & A & B & C & D & E & F \\
\hline Learners' translation & 1 & 4 & 0 & 2 & 66 & \\
method & 2 & 21 & 51 & & & \\
& 3 & 44 & 28 & 61 & 5 & \\
& 4 & 2 & 9 & & \\
\end{tabular}

As shown by Table 3, 66 of the students (91.67\%), through their responses to question 1, acknowledged three criteria for a good translation: accuracy, naturalness, and commucativeness as suggested by Larson (1998). The students' responses to question 2, however, demonstrated their orientation towards word-for-word translation approach $(51 / 72=$ $70.83 \%$ ) and their responses to question 3 revealed their entanglement in the structures and word orders in the English language in their translation process $(44 / 72=61.11 \%)$.

The students' responses to question 4 demonstrated their awareness of the importance of editing the translated text in terms of spelling, syntax, and semantics $(61 / 72=84.72 \%)$, but merely of self-editing it. Only five of the students $(6.94 \%)$ resort to a linguistics expert's editing and 19 of the students $(26.39 \%)$ resort to a medical expert's review.

- Analysis of the results from the investigation of learners' skill of translating medical terms.

TABLE 4.

LEARNERS' SKILL OF TRANSLATING MEDICAL TERMS

\begin{tabular}{|c|c|c|c|c|c|c|c|c|c|c|}
\hline \multirow[t]{3}{*}{ Question number } & \multicolumn{10}{|c|}{ Number and percentage of students who chose the answer } \\
\hline & \multicolumn{2}{|c|}{ A } & \multicolumn{2}{|c|}{$\mathrm{B}$} & \multicolumn{2}{|l|}{$\mathrm{C}$} & \multicolumn{2}{|l|}{$\mathrm{D}$} & \multicolumn{2}{|l|}{$\mathrm{E}$} \\
\hline & No & $\%$ & No & $\%$ & No & $\%$ & No & $\%$ & No & $\%$ \\
\hline 5 & & & & & & & & & & \\
\hline 5.1 & & & & & & & 16 & 22.22 & 56 & 77.78 \\
\hline 5.2 & 56 & 77.78 & 5 & 6.94 & 11 & 15.28 & & & & \\
\hline 5.3 & 62 & 86.11 & 7 & 9.72 & 3 & 4.17 & & & & \\
\hline 5.4 & 65 & 90.28 & 5 & 6.94 & 2 & 2.78 & & & & \\
\hline 6 & 8 & 11.11 & 30 & 41.67 & 34 & 47.22 & & & & \\
\hline 7 & 25 & 34.72 & 0 & 0.00 & 40 & 55.56 & 7 & 9.72 & 0 & 0.00 \\
\hline 8 & 9 & 12.50 & 63 & 87.50 & & & & & & \\
\hline 9 & 68 & 94.44 & 4 & 5.56 & & & & & & \\
\hline 10 & 55 & 76.39 & 17 & 23.61 & & & & & & \\
\hline 11 & 58 & 80.56 & 14 & 19.44 & & & & & & \\
\hline
\end{tabular}

The students' responses to question 5, as shown in Table 4, demonstrated that $77.78 \%$ of the students tended to visit English-Vietnamese medical dictionary upon encountering a new medical term in the source text; and high percentages of the students were unaccustomed to access to monolingual English medical dictionary (77.78\%), analysis of lexical roots $(86.11 \%)$, or decoding of the context $(90.28 \%)$, which are the crucial skills to explore the semantics of vocabulary.

As regards question 6 , even though $41.67 \%$ of the students selected the appropriate translation of the term "aphasia" (answer B), 47.22\% of the students deemed both answers A and B the correct translations of the term. Nevertheless, "speechlessness" as the hypernym of "aphasia" should be translated as "chứng nói không được" whereas "aphasia" should be translated as "chứng thất ngôn".

The students' responses to question 7, which sought to investigate learners' awareness of stylistic levels of technical terms, were not as expected, with $55.56 \%$ of the students choosing both translations for both terms, which implies their incapability to spot the distinction in stylistic levels between the two terms.

Questions 8 through 11 were meant to explore learners' capability to analyze the semantic components of a term as well as the relationship among these semantic components in the process of translating the medical. In contrast with the finding that $86.11 \%$ of the students were unaccustomed to analysis of lexical roots, $87.50 \%$ of the students and $94.44 \%$ of the students chose the appropriate translations in their responses to questions 8 and 9 respectively. $76.39 \%$ of the students and $80.56 \%$ of the students, however, selected the imprecise translations in their responses to questions 10 and 11 in turn. This contradiction was cleared up through the unstructured interview with the students, who contended to be conversant with the medical terms in questions 8 and 9, but inconversant with the medical terms in questions 10 and 11 , so they translated the medical terms in questions 10 and 11 in a reverse word order in the target language to that of English word order, but did not involve in the analysis of the relationship among their semantic components.

- Analysis of the results from the investigation of learners' skill of translating articles. 
TABLE 5.

LEARNERS' SKILL OF TRANSLATING ARTICLES

\begin{tabular}{|c|c|c|c|c|c|c|c|c|}
\hline \multirow[t]{3}{*}{ Question number } & \multicolumn{8}{|c|}{ Number and percentage of students who chose the answer } \\
\hline & \multicolumn{2}{|l|}{ A } & \multicolumn{2}{|l|}{$\mathrm{B}$} & \multicolumn{2}{|l|}{$\mathrm{C}$} & \multicolumn{2}{|l|}{$\mathrm{D}$} \\
\hline & No & $\%$ & No & $\%$ & No & $\%$ & No & $\%$ \\
\hline 12 & 33 & 45.83 & 4 & 5.56 & 23 & 31.94 & 12 & 16.67 \\
\hline 14 & 39 & 54.17 & 3 & 4.17 & 26 & 36.11 & 4 & 5.56 \\
\hline 15 & 14 & 19.44 & 32 & 44.44 & 9 & 12.50 & 17 & 23.61 \\
\hline 16 & 29 & 40.28 & 20 & 27.78 & 9 & 12.50 & 14 & 19.44 \\
\hline
\end{tabular}

As displayed in Table 5, the students' responses to questions 12 through 14, which aimed to explore learners' capability to translate English indefinite artile "a/an", indicated their inability to differentiate uses of this type of article: 1) denoting an indefinite object (in this case, "a/an" should be translated as "một" in Vietnamese language) and 2) denoting a general sense (in this case, "a/an" should not be translated). $45.83 \%, 44.44 \%$, and $54.17 \%$ of the students chose to translate "a/an" as "một" in their responses to the questions 12, 13, and 14 respectively. 31.94\%, 36.11\%, and $36.11 \%$ of the students regarded both translations as appropriate, but alleged that the translation "một" sounds more natural in Vietnamese language.

For question $15,44.44 \%$ of the students chose not to translate "a/an", and $23.61 \%$ of the students selected both translations, but considered untranslating "a/an" (due to its general sense) as more natural in the target language.

Questions 16 and 17 sought to investigate learners' ways to translate plurals from English to Vietnamese language. Question 16 looks at learners' awareness of the general sense of plurals and question 17 looks at learners' capability to distinguish uses of Vietnamese plural articles "các" and "những", and apply them in translating English plurals. The students' responses to questions 16 and 17 demonstrated their lack of expertise in translating plurals. For question 16, only $27.78 \%$ of the students chose to untranslate plurals or use zero article in the target language despite its most naturalness. For question 17, the Vietnamese plural "những" was the most appropriate translation, but was chosen by merely $20.83 \%$ of the students.

- Analysis of the results from the investigation of learners' skill of translating connectors

TABLE 6.

LEARNERS' SKILL OF TRANSLATING CONNECTORS

\begin{tabular}{|c|c|c|c|c|c|c|c|c|c|}
\hline \multirow[t]{3}{*}{ Connectors } & \multirow{3}{*}{$\begin{array}{l}\text { Question } \\
\text { number }\end{array}$} & \multicolumn{8}{|c|}{ Number and percentage of students who chose the answer } \\
\hline & & \multicolumn{2}{|l|}{ A } & \multicolumn{2}{|l|}{$\mathrm{B}$} & \multicolumn{2}{|l|}{$\mathrm{C}$} & \multicolumn{2}{|l|}{$\mathrm{D}$} \\
\hline & & No & $\%$ & No & $\%$ & No & $\%$ & No & $\%$ \\
\hline \multirow{5}{*}{$\begin{array}{l}\text { Connectors of } \\
\text { addition }\end{array}$} & 18 & 65 & 90.28 & 7 & 9.72 & 0 & 0 & 0 & 0 \\
\hline & 19 & 39 & 54.17 & 0 & 0 & 30 & 41.67 & 3 & 4.17 \\
\hline & 20 & 34 & 47.22 & 0 & 0 & 23 & 31.94 & 15 & 20.83 \\
\hline & 21 & 26 & 36.11 & 4 & 5.56 & 21 & 29.17 & 21 & 29.17 \\
\hline & 22 & 49 & 68.06 & 0 & 0 & 19 & 26.39 & 4 & 5.56 \\
\hline \multirow{10}{*}{$\begin{array}{l}\text { Connectors of } \\
\text { choice } \\
\text { Connectors of } \\
\text { comparison } \\
\text { Causal } \\
\text { connectors } \\
\text { Connectors of } \\
\text { contrast }\end{array}$} & 23 & 1 & 1.39 & 4 & 5.56 & 56 & 77.78 & 11 & 15.28 \\
\hline & 24 & 35 & 48.61 & 4 & 5.56 & 21 & 29.17 & 12 & 16.67 \\
\hline & 25 & 58 & 80.56 & 3 & 4.17 & 5 & 6.96 & 6 & 8.33 \\
\hline & 26 & 10 & 13.89 & 30 & 41.67 & 9 & 12.50 & 23 & 31.94 \\
\hline & 27 & 19 & 26.39 & 26 & 36.11 & 6 & 8.33 & 21 & 29.17 \\
\hline & 28 & 37 & 51.39 & 3 & 4.17 & 23 & 31.94 & 9 & 12.50 \\
\hline & 29 & 34 & 47.22 & 1 & 1.39 & 28 & 38.89 & 9 & 12.50 \\
\hline & 30 & 63 & 87.50 & 0 & 0.00 & 5 & 6.94 & 4 & 5.56 \\
\hline & 31 & 19 & 26.39 & 5 & 6.94 & 19 & 26.39 & 29 & 40.28 \\
\hline & 32 & 18 & 25.00 & 5 & 6.94 & 21 & 29.17 & 28 & 38.89 \\
\hline
\end{tabular}

As shown in Table 6, the students' responses to questions 18 through 22 seeking to investigate learners' competence to translate the connector of addition "and" indicated that majority of the students $(90.28 \%, 54.17 \%, 47.22 \%, 36.11 \%$, and $68.06 \%$ of the students in response to questions $18,19,20,21$, and 22 respectively) chose to translate "and" as "và" in Vietnamese language, equivalent to logical operator $\wedge$, or chose both translations with "và" regarded as more natural in the target language $(41.67 \%, 31.94 \%, 29.17 \%$, and $26.39 \%$ of the students in response to questions $19,20,21$, and 22 respectively). "And" in these questions, however, was not indicative of logical operator $\wedge$, but implied sequence relationship (translated as "rồi"), causal relationship (translated as "nên/cho nên" or "rồi/thì"), or contrastive relationship (translated as "còn" in Vietnamese language).

For question $23,77.78 \%$ of the students chose to translate the connector of choice "or" as "hay" (more oriented towards inclusive disjunction operator $\vee$ ) or "hoặc" (more oriented towards exclusive disjunction operator $\oplus$ ) with "hay" considered more natural in Vietnamese language. The connector of choice "or" in this instance, nonetheless, contained the implication of descriptive listing, which tends to emerge in scientific discourse and, in Nguyen's (2003, p. 491) view, should be expressed by "hoặc".

As regards question $24,48.61 \%$ of the students chose to translate the connector "or" as "hay", and $29.17 \%$ of the students chose both translations, but regarded "hay" as the more natural translation in Vietnamese language. The 
connector "or" in this case, however, is not a disjunction operator, but is meant to introduce a definition or elaboration for the noun preceding "or" and should be translated as "hay còn gọi là" ("or also called as") in the target language.

The students' responses to question 25 revealed that $80.56 \%$ of the students translated the connector "as" as "như là" in Vietnamese language; nevertheless, "như là" is the appropriate translation of the connector of comparison "like". The connector "as" implying "functioning" should be translated as "sử dụng ... làm ..." ("use ... as") in the context of this question.

Interestingly, the students' responses to question 26 demonstrated their mastery in translating causal connectors through the finding that $41.67 \%$ of the students chose to translate causal connector "because" as the paired conjunction "bởi vì ... cho nên ..." ("because ... so ...") in Vietnamese language and $31.94 \%$ of the students chose both translations with such a paired conjunction regarded as the more natural translation in the target language.

Likewise, the students' awareness of the distinction between English and Vietnamese expressions of concessive contrast was demonstrated via the finding from question 27 that $36.11 \%$ of the students chose to translate contrastive connector "despite the fact that" as the paired conjunction "mặc dù ... nhưng ..." ("although ... but ...") in Vietnamese language and $29.17 \%$ of the students chose both translations with such a paired conjunction regarded as the more natural translation in the target language. Questions 28 through 30 continued to investigate learners' capability to translate connectors of concessive contrast; however, their responses showed that they did not discern the variedness in Vietnamese expressions of concessive contrast, but stuck to the paired conjunction "mặc dù... nhưng..." ("although... but ...") as the sole translation for English contrastive connectors.

As displayed in Table 6, 40.28\% and $38.89 \%$ of the students deemed both translations to be appropriate in their responses to questions 31 and 32 respectively, but interestingly, more students $(40.28 \%>26.39 \%$ and $38.89 \%>$ 29.17\%) turned to more natural translations such as "mà" and "còn" to express the opposition relationship rather than abiding by the literal translation "nhưng" in the target language.

- Analysis of the results from the investigation of learners' skill of translating syntactic structures.

TABLE 7.

LEARNERS' SKILL OF TRANSLATING SYNTACTIC STRUCTURES

\begin{tabular}{|c|c|c|c|c|c|c|c|c|c|}
\hline \multirow{3}{*}{$\begin{array}{l}\text { Syntactic } \\
\text { structures }\end{array}$} & \multirow{3}{*}{$\begin{array}{l}\text { Question } \\
\text { number }\end{array}$} & \multicolumn{8}{|c|}{ Number and percentage of students who chose the answer } \\
\hline & & \multicolumn{2}{|l|}{ A } & \multicolumn{2}{|l|}{$\mathrm{B}$} & \multicolumn{2}{|l|}{$\mathrm{C}$} & \multicolumn{2}{|l|}{$\mathrm{D}$} \\
\hline & & No & $\%$ & No & $\%$ & No & $\%$ & No & $\%$ \\
\hline Nominalizations & 33 & 16 & 22.22 & 4 & 5.56 & 42 & 58.33 & 10 & 13.89 \\
\hline $\begin{array}{l}\text { Passive } \\
\text { constructions }\end{array}$ & $\begin{array}{l}34 \\
35\end{array}$ & $\begin{array}{l}31 \\
28\end{array}$ & $\begin{array}{l}43.06 \\
38.89\end{array}$ & $\begin{array}{l}11 \\
9\end{array}$ & $\begin{array}{l}15.28 \\
12.50\end{array}$ & $\begin{array}{l}24 \\
21\end{array}$ & $\begin{array}{l}33.33 \\
29.17\end{array}$ & $\begin{array}{l}6 \\
14\end{array}$ & $\begin{array}{l}8.33 \\
19.44\end{array}$ \\
\hline
\end{tabular}

As shown in Table 7, students' loyalty to the word-for-word translation of nominalizations was encountered from the finding that $22.22 \%$ of the students literally translated the nominalization and $58.33 \%$ of the students chose both literal translation and conversion of the nominalization into the verbal structure with literal translation regarded as the more appropriate translation in the target language.

Similarly, literal translation predominated among the students' responses to questions 35 and 35 , seeking to investigate learners' ways to translate English passive constructions, from the data that $76.39 \%(43.06 \%+33.33 \%)$ and $68.06 \%(38.89 \%+29.17 \%)$ of the students were more orientated towards the word-for-word simulation of English passive constructions in Vietnamese language.

Students, despite their ackowledgement of three criteria for a good translation: accuracy, naturalness, and commucativeness as proposed by Larson (1998), were prone to simulate English word orders and syntactic structures, and produce source-oriented translated texts due to their concern about missing out certain meanings in their translation process.

Impact of the application of Coordinate Translation Model (CTM) on the quality of learners' medical translation

TABLE 8

DESCRIPTIVE STATISTICS FOR MEDICAL TRANSLATION SCORES

\begin{tabular}{|c|c|c|c|c|c|}
\hline \multirow{2}{*}{ Groups } & \multirow{2}{*}{ Items } & \multicolumn{2}{|l|}{ Tests } & \multicolumn{2}{|c|}{ Changes } \\
\hline & & Pretest & Posttest & Value & Percentage \\
\hline \multirow{4}{*}{ CG } & Average scores & 6.09 & 6.32 & 0.23 & $3.78 \%$ \\
\hline & Average number of serious mistakes per translated text & 18.21 & 13.89 & -4.32 & $-23.72 \%$ \\
\hline & Number of unfinished pieces & 13 & 10 & -3 & $-23.08 \%$ \\
\hline & Number of submitted translated texts & 38 & 38 & & \\
\hline \multirow[t]{3}{*}{ EG } & Average number of minor mistakes per translated text & 5.16 & 3.21 & -1.95 & $-37.79 \%$ \\
\hline & Number of unfinished pieces & 16 & 9 & -7 & $-43.75 \%$ \\
\hline & Number of submitted essays & 41 & 41 & & \\
\hline $\begin{array}{l}\text { Difference between } \\
\text { EG and CG }\end{array}$ & Average scores & -0.21 & 1.65 & 1.86 & $31.76 \%$ \\
\hline
\end{tabular}


The data from Table 8 substantiate that an insignificant disparity (-0.21) was encountered between the experimental group and the control group in terms of average pretest score. The average pretest score achieved by the students in the experimental group was 5.88 points and that by the students in the control group was 6.09 points.

However, the average posttest scores earned by the students in both groups significantly diverged. The average posttest score gained by the students in the experimental group increased by 2.09 points (35.54\%) compared to the average pretest score, while that in the control group increased merely by 0.23 points $(3.78 \%)$ compared to the average pretest score.

Since the calculation of students' scores was predicated on the analysis of serious errors and minor errors in translated texts, the results of the average number of serious errors and that of minor errors were also displayed in Table 8.

The average number of serious errors and that of minor errors left in the pretest papers by the students in the control group was 18.21 and 6.59 respectively, and the average number of serious errors and that of minor errors by the students in the experimental group was 20.08 and 5.16, indicating that at the departure of medical translation practice, the students's translation competence did not substantially differ.

The fourteen-week practice of medical translation, nonetheless, brought about a discernible divergence in the average number of mistakes made by the students between the two groups. The average number of serious mistakes and that of minor mistakes made by the students in the experimental group fell by 10.52 mistakes (52.39\%) and by 1.95 (37.79\%) respectively in the posttest compared with the pretest, whereas the average number of serious mistakes made by the students in the control group dropped by 4.32 mistakes $(23.72 \%)$ and that of minor mistakes rose by 6.11 mistakes (92.72\%) (implying that some serious mistakes were promoted to minor mistakes, but did not vanish) in the posttest compared with the pretest, which implies that the students in the experimental group demonstrated the better progress in the level of translation competence than those in the control group.

Besides translation scores and errors, learners' improvement in translation competence is partially manifested through the extent of translation task completion. The students in the experimental group demonstrated the better enhancement in the extent of translation task completion than those in the control group. The disparity in the number of unfinished translation pieces submitted by the students in the experimental group between the postest and the pretest was -3.0 pieces $(-23.08 \%)$ while that in the control group between the posttest and the pretest was -7.0 pieces $(-43.75 \%)$.

\section{CONCLUDING REMARKS}

Most translation models have looked at procedures to render linguistic units and stylistic properties from the source text into the target language so as to attain the criteria for a good translation such as accuracy, naturalness, and commucativeness as suggested by Larson (1998). These translation models, nonetheless, place the source text on the two-dimensional plane to decompose the text into units, then render them into the target language through an assembly process using materials the target language. Coordinate Translation Model (CTM), proposed by the author of the study, lays the source text in the three-dimensional space where it is scanned by the translation unit scanner, concept equivalent scanner, and schema scanner. The research substantiated the benefits of the application of Coordinate Translation Model (CTM) in medical translation practice through a discernible divergence in the average posttest scores earned by the students in the experimental group and the control group. The research, moreover, demonstrated that translation skills can be acquired through an effective translation approach.

APPENDiX 1. MEDICAL TRANSLATION SKILLS SURVEY

\section{General}

1. Age :

2. Gender: Male $\square \quad$ Female $\square$

3. How long have you studied English?

How do you assess your own English competence?

Reading: $\quad$ Poor $\square \quad$ Adequate $\square \quad$ Good $\square \quad$ Excellent $\square$

4. How long have you been exposed to medical English? (including classroom study and self-study)

How do you assess your own medical English competence?

Reading: $\quad$ Poor $\square \quad$ Adequate $\square \quad$ Good $\square \quad$ Excellent $\square$

5. Do you think translation skill is necessary for medical students and medical professionals?

(A) Yes

(B) No

6. If "yes", translation skill helps them (more than one answer can be picked)

(A) to translate medical materials

(B) to read and comprehend medical materials through translation

(C) other reasons: 


\section{Investigating learners' medical translation skill}

Circle A, B, C, or D to respond to the questions as guided.

For questions 1 through 11 (except questions 4 and 5), please select the best answer.

- Learners' translation method

1. In your view, a good translation must

A. be a word-for-word translation of the source text

B. be natural in Vietnamese language.

C. be comprehensible for readers.

D. all of the above

2. Upon translating a medical material, you tend to

A. read and comprehend the whole paragraph or passage before starting to translate it.

B. translate word after word or sentence after sentence.

3. Upon translating an English sentence, you tend

A. to cling to structure and word order in the English sentence.

B. to reproduce the semantics of that sentence in Vietnamese structure and word order.

4. Upon accomplishing the translation of a medical text, you tend (more than one answer can be picked)

A. not to review the translation.

B. to review merely to locate and fix spelling and grammatical errors.

C. to review to locate and fix spelling, grammatical, and semantic errors.

D. to send it to a linguistics expert to review and comment.

E. to send it to a medical expert to review and comment.

F. to send it to a person outside the fields of linguistics and medicine to review and comment.

- Learners' skill of translating medical terms

5. Encountering a new medical term in the translation process, you (select the responses to questions 5.1, 5.2, 5.3 and 5.4 on the Likert scale)

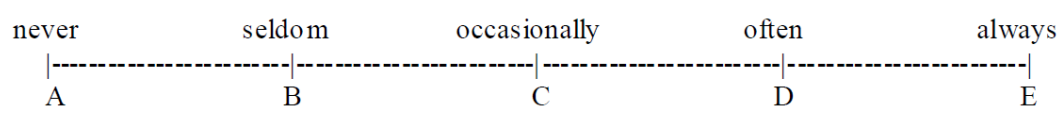

5.1 instantaneously visit English-Vietnamese medical dictionary.

5.2 visit monolingual English medical dictionary and infer its meaning.

5.3 analyze its lexical roots and infer its meaning.

5.4 explore its context and search your medical knowledge to infer its meaning.

6. The term "aphasia" refers to an acquired disorder of language that results from damage to portions of the brain that are responsible for language, so should be translated as

A. chứng không nói được

B. chứng thất ngôn

C. both (A) and (B) are correct, but (A) denotes popular stylistic level whereas (B) denotes academic stylistic level.

7. "Uterus" and "womb" are synonyms in English language; however, "uterus" indicates academic stylistic level and "womb" indicates popular stylistic level, so which of the subsequent is the best translation?

A. Both "uterus" and "womb" should be translated as "tử cung".

B. Both "uterus" and "womb" should be translated as "da con".

C. Both "uterus" and "womb" can be translated as "tử cung" or "dạ con".

D. "Uterus" should be translated as "tử cung" whereas "womb" should be translated as "dạ con".

E. "Uterus" should be translated as "dạ con" whereas "womb" should be translated as "tử cung".

8. The Latin root ped-implies leg, so the term pediatrics means

A. khoa chi dưới

B. khoa nhi

9. The phrasal term "Vesico-ureteral reflux" should be translated as

A. Trào ngược bàng quang-niệu quản

$B$. Trào ngược niệu quản-bàng quang

10. The phrasal term "Acute drug induced tubuloinstertial nephritis" should be translated as

A. Viêm ống thận mô kẽ do thuốc cấp tính

B. Viêm ống thận mô kẽ cấp tính do thuốc

11. The phrasal term "Lateral amyotrophic schlerosis" should be translated as

A. Bệnh xơ cứng teo cơ ở cột bên

B. Bệnh xơ cứng cột bên teo cơ 
For questions 12 through 35 , please choose

A. if the translated text (1) sounds appropriate and natural in Vietnamese language.

B. if the translated text (2) sounds appropriate and natural in Vietnamese language.

C. if both (1) and (2) are correct, but (1) sounds better than (2).

D. if both (1) and (2) are correct, but (2) sounds better than (1).

your suggested translation:

- Learners' skill of translating articles

12. Source text: To a doctor the term diarrhoea means frequent passing of watery stools.

Translated text:

(1) Đối với một bác sĩ, thuật ngữ tiêu chảy có nghĩa là thường xuyên đi tiêu toàn phân loãng.

(2) Đối với thầy thuốc, thuật ngữ tiêu chảy có nghĩa là thường xuyên đi tiêu toàn phân loãng.

13. Source text: An abcess can occur in any part of the body. If it is in the lung, the patient may have a cough and difficulty in breathing.

Translated text:

(1) Một áp xe có thể xuất hiện ở bất kỳ bộ phận nào của cơ thể. Nếu nó nằm ở phổi, bệnh nhân có thể có một cơn ho và khó thở.

(2) Áp xe có thể xuất hiện ở bất kỳ bộ phận nào của cơ thể. Nếu áp xe nằm ở phổi, bệnh nhân có thể bị ho và khó thở.

14. Source text: One protein is a straight line, two is a curved line, and three is a blob.

Translated text:

(1) Một phân tử protein có hình dạng một đường thẳng, hai phân tử protein có hình dạng một đường cong, ba phân tử protein thì có hình dạng một khối cuộn.

(2) Một phân tử protein có hình dạng đường thẳng, hai phân tử protein có hình dạng đường cong, ba phân tử protein thì có hình dạng khối cuộn.

15. Source text: The word constipation means different things to different people; to the doctor it means the passage of hard and infrequent stools.

Translated text:

(1) Thuật ngữ “táo bón” có ý nghĩa khác nhau đối với từng người; song đối với vị bác sĩ này, táo bón có nghĩa là đi tiêu phân cứng và không nhiều.

(2) Thuật ngữ “táo bón” có ý nghĩa khác nhau đối với từng người; song đối với thầy thuốc, táo bón có nghĩa là đi tiêu phân cứng và không nhiều.

16. Source text: Murmurs are noises from the heart caused by a disturbance in the flow of blood as it passes through the heart and great vessels.

Translated text:

(1) Các âm thổi là những tiếng động phát ra từ tim do dòng máu bị rối loạn khi lưu thông qua tim và các mạch máu.

(2) Âm thổi là những tiếng động phát ra từ tim do dòng máu bị rối loạn khi lưu thông qua tim và các mạch máu.

17. Source text: Murmurs which are caused by insignificant or slight changes in the flow of blood are called innocent murmurs.

Translated text:

(1) Các âm thổi do những thay đổi không đáng kể trong dòng máu gây ra gọi là âm thổi vô tội.

(2) Những âm thổi do những thay đổi không đáng kể trong dòng máu gây ra gọi là âm thổi vô tội.

- Learners' skill of translating connectors

18. Source text: The bread and butter turns sour since germs have grown in it.

Translated text:

(1) Bánh mì và bơ có vị chua vì có mầm bệnh phát triển trong nó.

(2) Bánh mì bơ có vị chua vì có mầm bệnh phát triển trong nó.

19. Source text: Pain in peptic ulcer disease is almost always episodic, lasting several days to weeks and is followed by a remission of months.

Translated text:

(1) Cơn đau trong bệnh loét dạ dày-tá tràng thường diễn biến từng đợt, đau kéo dài nhiều ngày đến nhiều tuần, và lui đi trong nhiều tháng.

(2) Cơn đau trong bệnh loét dạ dày-tá tràng thường diễn biến từng đợt, đau kéo dài nhiều ngày đến nhiều tuần, rồi lui đi trong nhiều tháng.

20. Source text: Alexander Fleming noticed a halo of inhibition of bacterial growth in a culture of Staphylococcus around a contaminant blue-green mould, and he concluded that the mould was realeasing a substance that was inhibiting bacterial growth.

Translated text:

(1) Alexander Fleming phát hiện thấy một vòng kiềm khuẩn quanh lớp nấm mốc màu xanh trong đĩa nuôi cấy vi khuẩn Staphylococcus, và ông kết luận rằng nấm mốc sinh ra một chất gì đó ức chế vi khuẩn phát triển.

(2) Alexander Fleming phát hiện thấy một vòng kiềm khuẩn quanh lớp nấm mốc màu xanh trong đĩa nuôi cấy vi khuẩn Staphylococcus, nên/cho nên ông kết luận rằng nấm mốc sinh ra một chất gì đó ức chế vi khuẩn phát triển. 
21. Source text: Observe carefully and you will find out the things the patient doesn't tell you.

Translated text:

(1) Hãy quan sát kỹ và bạn sẽ khám phá ra những điều người bệnh không kể với bạn.

(2) Hãy quan sát kỹ rồi / thì bạn sẽ khám phá ra những điều người bệnh không kể với bạn.

22. Source text: Arteries carry blood out of the heart and veins carry blood back to the heart.

Translated text:

(1) Động mạch vận chuyển máu ra khỏi tim và tĩnh mạch đưa máu về tim.

(2) Động mạch vận chuyển máu ra khỏi tim còn tĩnh mạch đưa máu về tim.

23. Source text: Cardiogenic syncope most commonly results from loss of sinus node impulse, atrioventricular conduction block, or ventricular tachycardia or fibrillation.

Translated text:

(1) Ngất tim thường xảy ra do liệt nút xoang, blốc nhĩ-thất, hay do nhịp nhanh thất hay rung thất.

(2) Ngất tim thường xảy ra do liệt nút xoang, blốc nhĩ-thất, hoặc do nhịp nhanh thất hoặc rung thất.

24. Source text: The ileum has in its wall opposite the mesentery distinctive patches of lymphoid tissue, or Peyer's patches.

Translated text:

(1) Trong thành của hồi tràng đối diện với mạc treo ruột có những mảng mô bạch huyết đặc trưng, hay mảng Peyer.

(2) Trong thành của hồi tràng đối diện với mạc treo ruột có những mảng mổ bạch huyết đặc trưng, hay còn gọi là mảng Peyer.

25. Source text: Peritoneal dialysis uses the peritoneum as a dialysis membrane.

Translated text:

(1) Thẩm phân phúc mạc sử dụng phúc mạc như một màng thẩm phân.

(2) Thẩm phân phúc mạc sử dụng phúc mạc làm màng thẩm phân.

26. Source text: Because the body produces sufficient quantities of some but not all vitamins, they must be supplemented in the daily diet.

Translated text:

(1) Bởi vì cơ thể sản xuất đủ số lượng một số loại vitamin chứ không phải tất cả các loại vitamin, vitamin vẫn cần phải bổ sung trong khẩu phần ăn hàng ngày.

(2) Bởi vì cơ thể sản xuất đủ số lượng một số loại vitamin chứ không phải tất cả các loại vitamin, cho nên vitamin vẫn cần phải bổ sung trong khẩu phần ăn hàng ngày.

27. Source text: Despite the fact that the brain comprises only 2 percent of the body's weight, it receives 20 percent of all the blood pumped from the heart.

Translated text:

(1) Mặc dù bộ não chỉ chiếm $2 \%$ trọng lượng cơ thể, nó nhận $20 \%$ lượng máu bơm ra từ tim.

(2) Mặc dù bộ não chỉ chiếm $2 \%$ trọng lượng cơ thể, nhưng nó nhận $20 \%$ lượng máu bơm ra từ tim.

28. Source text: Though the patient was hospitalised with the manifestation of heart failure without chest pain, myocardial infartion should not be ignored.

Translated text:

(1) Dù bệnh nhân nhập viện trong bệnh cảnh suy tim không đau ngực, nhưng không loại trừ nhồi máu cơ tim.

(2) Dù bệnh nhân nhập viện trong bệnh cảnh suy tim không đau ngực, cũng không loại trừ nhồi máu cơ tim.

29. Source text: Although Pasteur could not see the bacteria, he managed to produce vaccine.

Translated text:

(1) Dù Pasteur không nhìn thấy vi trùng, nhưng ông điều chế được vaccine.

(2) Dù Pasteur không nhìn thấy vi trùng, ông vẫn điều chế được vaccine.

30. Source text: Although Pasteur could not see the bacteria, he managed to produce vaccine.

Translated text:

(1) Dù Pasteur không nhìn thấy vi trùng, nhưng ông điều chế được vaccine.

(2) Chưa nhìn thấy vi trùng, mà Pasteur đã điều chế được vaccine.

31. Source text: Eijkman finally found out that beri-beri was not an infectious, but a nutritional deficiency disease. Translated text:

(1) Eijkman cuối cùng phát hiện ra rằng bệnh beri-beri không phải là bệnh nhiễm trùng, nhưng do suy dinh dưỡng.

(2) Eijkman cuối cùng phát hiện ra rằng bệnh beri-beri không phải là bệnh nhiễm trùng mà là do suy dinh dưỡng.

32. Source text: The right atrio-ventricular orifice is closed by three flaps, but the left atrio-ventricular orifice is closed by two flaps.

Translated text:

(1) Lỗ nhĩ-thất phải đóng bởi van 3 lá, nhưng lỗ nhĩ-thất trái đóng bởi van 2 lá.

(2) Lỗ nhĩ-thất phải đóng bởi van 3 lá, còn lỗ nhĩ-thất trái đóng bởi van 2 lá.

- Learners' skill of translating nominalizations

33. Source text: Physicians must remain sensitive to the complexity and stress of hospitalization.

Translated text: 
(1) Thầy thuốc phải nhạy cảm với sự bối rối và căng thẳng của việc nhập viện.

(2) Thầy thuốc phải hiểu và thông cảm với trạng thái bối rối và căng thẳng của người bệnh khi phải nhập viện.

- Learners' skill of translating passive constructions

34. Source text: Scleroderma is a systemic illness of unknown cause characterized by sclerotic skin changes and often accompanied by multisystem disease.

Translated text:

(1) Bệnh xơ cứng bì là một bệnh hệ thống chưa rõ nguyên nhân được đặc trưng bởi tình trạng xơ cứng da và thường đi kèm bởi bệnh đa hệ thống.

(2) Bệnh xơ cứng bì là một bệnh hệ thống chưa rõ nguyên nhân có đặc trưng là tình trạng xơ cứng da và thường có bệnh đa hệ thống đi cùng.

35. Source text: Infective endocarditis is usually caused by gram-positive cocci, although gram-negative bacilli and fungi may also produce the disease.

Translated text:

(1) Viêm nội tâm mạc nhiễm trùng thường được gây ra bởi cầu khuẩn Gram + , mặc dù trực khuẩn Gram - và nấm cũng có thể gây bệnh.

(2) Viêm nội tâm mạc nhiễm trùng thường do cầu khuẩn Gram + gây ra, mặc dù trực khuẩn Gram - và nấm cũng có thể gây bệnh.

\section{REFERENCES}

[1] Bui, V.N.S (2006). Dịch thuật và học thuật (Translation and learning). Retrieved on May 242006 from http://vietnamnet.vn/vanhoa/chuyende/2006/01/537087.

[2] Cao, V.D. (2005). Suy nghĩ về dịch thuật và ngôn ngũu văn chuơng (Thoughts on Translation and Literary Language). Retrieved on July 92008 from http://vietnamnet.vn/vanhoa/chuyende/2005/12/526939/

[3] Fishbach, H. (1993). Translation, the great pollinator of science: a brief flashback on medical translation. Babel, 38 (4): $193-$ 202.

[4] Green, D.W. (1998a). Mental control of the bilingual lexico-semantic system. Bilingualism, No. 1, pp. 67-81.

[5] Green, D.W. (1998b). Schemas, tags and inhibition. Reply to commentators. Bilingualism, No. 1, pp. 100-4.

[6] Hurtado Albir, A. (1995). La didáctica de la traducción. Evolución y estado actual. X Perspectivas de la Traducción, (P. Fernández, ed.), Valladolid, Universidad de Valladolid, pp. 49-74.

[7] Karra, M. (2000). Science or translation. Translation Journal, Volume 4, No. 1, January 2004. Retrieved on March 142004 from http://accurapid.com/journal/11sci.htm.

[8] Kelly, L. G. (2004). The History of Translation. Retrieved on February 5 2004 from http://www.completetranslation.com/history.htm.

[9] Koller, W. (1992). Einführung in die Übersetzungwissenschaft. Heidelberg, Wiesbaden: Quelle \& Meyer Verlag.

[10] Larson, M.L. (1998). Meaning-based Translation: A Guide to Cross-language Equivalence. Lanham, MD: University Press of America and Summer Institute of Linguistics.

[11] Newmark, P. (1988). A textbook of translation. London: Prentice Hall Europe.

[12] Nguyen, V.T. (2003). Tiếng Việt hiện đại (Modern Vietnamese language). Hanoi: Social Sciences Publishing House.

[13] Snell-Hornby, M. (1988). Translation Studies. An Integrated Approach. Amsterdam: John Benjamins Publishing Company.

[14] Steiner, G. (1975). After Babel: Aspects of Language and Translation. London: Oxford University Press.

[15] Stringer, E.T. (1999). Action Research (2 $2^{\text {nd }}$ ed.). California: SAGE Publications.

[16] Waddington, C. (2001). Different Methods of Evaluating Student Translation: The Question of Validity. Meta, XLVI, 2.

[17] Weaver, W. (1989). The process of Translation. In Biguenet, J. \& Schulte, R. (Ed.), The Craft of Translation. Chicago: University of Chicago Press.

[18] Zhu, C. (1999). Ut once more: The sentence as the key functional unit of translation. Meta: Translators' Journal, Vol. 44, No. 3 , pp. 429-447.

Luu Trong Tuan is currently an EFL teacher at University of Finance-Marketing, Ho Chi Minh City. He received his M.TESOL from Victoria University, Australia in 2004. Besides his focus on TESOL, his recent publications such as Language Transfer is Cultural Transfer between Communities, Social Sciences Review, No. 11, 2004, pp. 60-63; and Principles for Scientific Translation, Social Sciences Review, No. 8, 2004, pp. 63-67; and Building Vietnamese Medical Terminology via Language Contact, Australian Journal of Linguistics, Vol. 29, No. 3, September 2009, pp. 315-336 show his interest in language contact and translation areas. 